\title{
Design and optimization of self-microemulsifying drug delivery system (SMEDDS) of felodipine for chronotherapeutic application
}

\author{
Khalid Akhter Ansari" ${ }^{1, ~}$, Kunal Pratap Pagar ${ }^{1}$, Shoeb Anwar², Pradeep Ratilal Vavia ${ }^{1}$ \\ ${ }^{1}$ Department of Pharmaceutical Sciences and Technology, Institute of Chemical Technology, Nathalal Parikh Marg, India, \\ ${ }^{2}$ M.C.E Society's Allana College of Pharmacy, Azam campus Pune-4000019, India
}

\begin{abstract}
The objective of this research work was to design, develop and optimize the self micro-emulsifying drug delivery system (SMEDDS) of Felodipine (FL) filled in hard gelatine capsule coated with polymer in order to achieve rapid drug release after a desired time lag in the management of hypertension. Microemulsion is composed of a FL, Lauroglycol FCC, Transcutol P and Cremophor EL. The optimum surfactant to co-surfactant ratio was found to be $2: 1$. The resultant microemulsions have a particle size in the range of $65-85 \mathrm{~nm}$ and zeta potential value of $-13.71 \mathrm{mV}$. FL release was adequately adjusted by using $\mathrm{pH}$ independent polymer i.e. ethyl cellulose along with dibutyl phthalate as plasticizer. Influence of formulation variables like viscosity of polymer, type of plasticizer and percent coating weight gain was investigated to characterize the time lag. The developed formulation of FL SMEDDS capsules coated with ethyl cellulose showed time lag of 5-7 h which is desirable for chronotherapeutic application.
\end{abstract}

Uniterms: Felodipine/self-microemulsifying delivery. Felodipine/chronotherapeutic application. Selfmicroemulsifying drug delivery system/development. Drugs/controlled release. Ethyl cellulose/drugs coated. Hypertension/treatment. Chronotherapeutics/hypertension treatment.

O objetivo desse trabalho de pesquisa foi planejar, desenvolver e otimizar sistema de liberação de fármaco auto-microemulsificante(SMEDDS) de felodipino (FL) em cápsulas de gelatina dura revestidas com polímero, a fim de obter liberação rápida após tempo desejado no manejo da hipertensão. A microemulsão é composta de FL, lauroglilcol FCC, Transcutol P e Cremophor EL. A proporção ótima de tensoativo e de co-tensoativo foi de 2:1. As microemulsões resultantes têm tamanho de partícula na faixa de $65-85 \mathrm{~nm}$ com potencial zeta de $-13,71 \mathrm{mV}$. A liberação de FL foi ajustada adequadamente, utilizando-se polímero independente de $\mathrm{pH}$, como etilcelulose com ftalato de dibutila como plastificante. A influência das variáveis da formulação, como viscosidade do polímero, tipo de plastificante e ganho percentual de peso do revestimento foi investigada para caracterizar o intervalo de tempo de liberação. A formulação de cápsulas de FL SMEDDS revestidas com etilcelulose mostrou intervalo de tempo de liberação de 5 a 7 horas, o que é desejável para uma aplicação cronoterapêutica.

Uniterms: Felodipino/liberação de fármaco auto-emulsificante. Felodipino/aplicação cronoterapêutica. Sistema de liberação de fármaco auto-emulsificante/desenvolvimento. Fármacos/liberação controlada. Etilcelulose/revestimento de fármacos. Hipertensão/tratamento. Cronoterapia/tratamento da hipertensão.

\section{INTRODUCTION}

The key to the success of any drug delivery system depends upon the development of formulations that accomplish the therapeutic needs associated with particular pathological condition or disease state (Lemmer, 1991). It has been observed that many physiological functions (e.g. blood pressure, hormonal levels) and pathophysiological

*Correspondence: Khalid Akhter Ansari. Formulation Development Centre, Syngene International Ltd, 560099 - Biocon Park - Bangalore, India. E-mail: khalid.akhter@gmail.com disease states (e.g. hypertension, myocardial infarction, cancer, bronchial asthma and rheumatic disease) show a circadian pattern in their manifestations i.e. the disease symptoms do not occur evenly for the twenty-four hours of the day but undergo significant daily variations (Lemmer, 2012; Francis et al., 2010). Therefore, the ideal remedy for such disease states should preferentially involve formulations that release drugs after a specified delay period (lag period-time of no drug release) after dosing by the patient (Michael et al., 2007). Thus, drug release from the formulation will be targeted to a specific period of the day when there is higher chances of clinical 
manifestation of the disease. Such a delivery approach is termed as chronotherapeutic (chronos-time) (Mandal et al., 2010; Youan, 2004).

Hypertension is a common chronic condition affecting up to $35 \%$ of human adults and showed circadian variation in manifestations (Hermida et al., 2007). Cardiovascular events happen more often in the morning, and ambulatory blood pressure (BP) exhibits a diurnal variation with increase in the morning (morning BP surge). The morning BP surge was reported to be associated with high risk of cardiac death, and ischemic and hemorrhagic stroke (Nayak et al., 2009; Cohen et al., 1997; Behrens et al., 1997). Blood pressure which arises notably just before waking up is usually responsible for these attacks and deaths (Karavas et al., 2006). Therefore, the chronotherapeutic drug delivery approach should be the ideal remedy for the treatment of hypertension in order to tackle the early morning mortality associated with such disease state.

Felodipine (FL), which is used in the proposed research, belongs to a category of dihydropyridine derivative. It is chemically described as ethylmethyl-4-(2,3dichlorophenyl)-1,4-dihydro-2,6-dimethyl-3,5-pyridinecarboxylate [USP (United States Pharmacopoeia 29). FL is a calcium antagonist used commonly for its excellent antihypertension and antianginal effects (Teberekidis et al., 2007). FL is a poorly water soluble drug belonging to the category of BCS class II (Yasir et al., 2010). The bioavailability of FL is strongly limited by its high lipophilic character (aqueous solubility $<0.5 \mathrm{mg} / \mathrm{L}$ ) (Abrahamsson et al., 1994). Literature reports the chronotherapeutic drug delivery of FL using polyvinyl pirrolidone/hydroxypropyl methylcellulose (PVP/HPMC) nanodispersion which is responsible for bioavailability enhancement of FL (Lemmer, 1991; Evangelos et al., 2006) and also the extended release FL self-nanoemulsifying system (Patil et al.,2009). Thus, effective formulation design can be a useful approach which results in improved solubility, absorption and in total oral bioavailability of such drug candidates (Pouton et al., 2006). There are the several formulation approaches to increase the solubility of poorly water soluble drugs like cyclodextrin, nanosponges and nanoparticles (Khalid et al., 2011; Khalid et al., 2011; Satyen et al. 2010; Francesco et al., 2011; Ridhurkar et al., 2012; Nekkanti et al., 2011). However, Self-microemulsifying drug delivery systems (SMEDDS) are among the methods used to improve the oral bioavailability of poorly soluble drugs (Hong et al., 2006). SMEDDS comprise isotropic mixtures of natural or synthetic oils with surfactants and co-surfactants. These systems spontaneously emulsify when exposed to gastrointestinal (GIT) fluids to form oil in water microemulsion with nanometric droplet size, in the range of 20-200 nm (Basalious et al., 2010). Furthermore, they can improve oral bioavailability through enhancing permeation across the intestinal membrane, solubilization, droplet size reduction and improvement of drug dissolution (Wang et al., 2010; Wasan et al., 2009). Self-microemulsifying system of FL would be an efficient, convenient and more patient compliant approach as SMEDDS can be filled in hard gelatine capsules due to their anhydrous nature enabling its administration as unit dosage form.

In the present work, FL SMEDDS was prepared which was subsequently used in chrono-capsules formulation. The objectives of the present study were, first, to develop a SMEDDS of FL to increase the bioavailability and to formulate time delayed chronotherapeutic capsule formulation of $\mathrm{FL}$ using $\mathrm{pH}$ independent polymer as a functional coating material. Different viscosity grades of ethyl cellulose along with hydrophobic plasticizer will be used as functional coating material. Such a hydrophobic coating layer will act as an alarm clock releasing the drug amount from the active core at the predictable time.

\section{MATERIAL AND METHODS}

\section{Raw Material}

Felodipine (FL) was procured from Nivedita Chemicals Pvt. Ltd. (Mumbai, India). Cremophor EL (CEL) (BASF, Mumbai, India), Transcutol P (TP) (BASF, Mumbai, India), Lauroglycol FCC (LFCC) (Colorcon Asia Pvt. Ltd., Mumbai, India), Ethyl cellulose (EC N7, EC N10, EC N22) (Colorcon Asia Pvt. Ltd., Mumbai, India) and Hard gelatin capsules (Associated Capsules, Mumbai, India) were obtained as gift samples. All other chemicals and reagents were of analytical grade. HPLC grade solvents were used in case of HPLC analysis. Milli-Q water was used in all experiments.

\section{Methods}

\section{Solubility studies}

Solubility of FL in various components (oils, surfactants and co-surfactants) was determined. Briefly, $500 \mathrm{mg}$ of each of the selected vehicle were added in vial containing an excess of FL (1 gram). After sealing the vial, the mixtures were shaken at $30 \pm 0.5^{\circ} \mathrm{C}$ for $48 \mathrm{~h}$ with thermostatically controlled water bath shaker (Remi, India). After $48 \mathrm{~h}$, the mixtures were centrifuged at $3000 \mathrm{rpm}$ for $5 \mathrm{~min}$ (Research Compufuge, Remi, India) and an excess insoluble FL was discarded by filtration using a membrane filter $(0.45 \mu \mathrm{m}, 13 \mathrm{~mm}$, Whatman, 
USA). Concentration of FL in each component was quantified by HPLC. The analysis was carried out on a Waters 717 autosampler chromatographic system (Waters, India) equipped with waters 515 HPLC pump and waters 2487 dual wavelength detector using Lichrosphere C-18 Merck $(250 \mathrm{~mm} \times 4.6 \mathrm{~mm} ; 5 \mu \mathrm{m})$ (Thermoelectron, USA) at a flow rate of $1.0 \mathrm{~mL} / \mathrm{min}$ [Mobile Phasebuffer: acetonitrile: methanol (40:40:20] (USP 29). The analysis was carried out at $254 \mathrm{~nm}$. The linearity of FL was accomplished in the range of $240-360 \mu \mathrm{g} / \mathrm{mL}$. The HPLC chromatogram of drug showed very sharp peak at retention time of $20.288 \mathrm{~min}$ (Figure 1). Each experiment was carried out in triplicate. The components showing maximum solubilization were selected for further studies.

\section{Selection of surfactant to co-surfactant ratio}

Ratio of surfactant to co-surfactant is an important consideration for formulating microemulsion based system. Cremophor EL (CEL) as a surfactant and Transcutol P (TP) as a co-surfactant were used during the study. Turbidimetric method was used to assess relative efficacy of the cosurfactant to improve the microemulsification ability of the surfactants and to select best one from the large pool of co-surfactants available for peroral delivery (Date et al., 2007). CEL: TP $(2: 1 \mathrm{v} / \mathrm{v})$ was mixed with oil and the mixture was homogenized with the aid of the gentle heat $\left(40-50{ }^{\circ} \mathrm{C}\right)$. The isotropic mixture was accurately weighed and diluted to $50 \mathrm{~mL}$ with water to yield fine emulsion. The ease of formation of emulsion was observed by noting the number of volumetric flask inversions required to give uniform emulsion. The resulting emulsions were observed visually for the relative turbidity.

\section{Preparation of SMEDDS}

SMEDDS containing FL was prepared by mixing oil phase with surfactant and co-surfactant using vortex mixer. Oil Phase i.e. lauroglycol FCC (LFCC) was accurately weighed and transferred into microemulsion tube followed by addition of surfactant (CEL) and co-surfactant (TP) in order to prepare blank SMEDDS. Concentration of the three components totalled to $100 \%$. Drug loaded SMEDDS were prepared by keeping drug content constant as $0.1 \mathrm{mg} / \mathrm{g}$ of the prepared SMEDDS. The composition of FL SMEDDS formulation is given in Table I.

TABLE I - Composition of felodipine SMEDDS formulation

\begin{tabular}{lc}
\hline Components & Amount (mg) \\
\hline Felodipine & 10 \\
Lauroglycol FCC & 40 \\
Cremophor EL: Transcutol P $(2: 1 \mathrm{v} / \mathrm{v})$ & 60 \\
\hline
\end{tabular}

\section{Self emulsification and flowability}

Evaluation of self-emulsifying properties of SMEDDS formulation was carried out by visual assessment as previously reported (Khoo et al., 1998). Briefly, different compositions having oil and different surfactant to co-surfactant ratios of were categorized on apparent clarity of the resultant emulsion. Visual assessment was performed by drop wise addition of the pre-concentrate (SMEDDS) into $250 \mathrm{~mL}$ water. This was performed in a glass beaker at room temperature and the contents were gently stirred magnetically at approximately $100 \mathrm{rpm}$. The compositions were categorized based on the

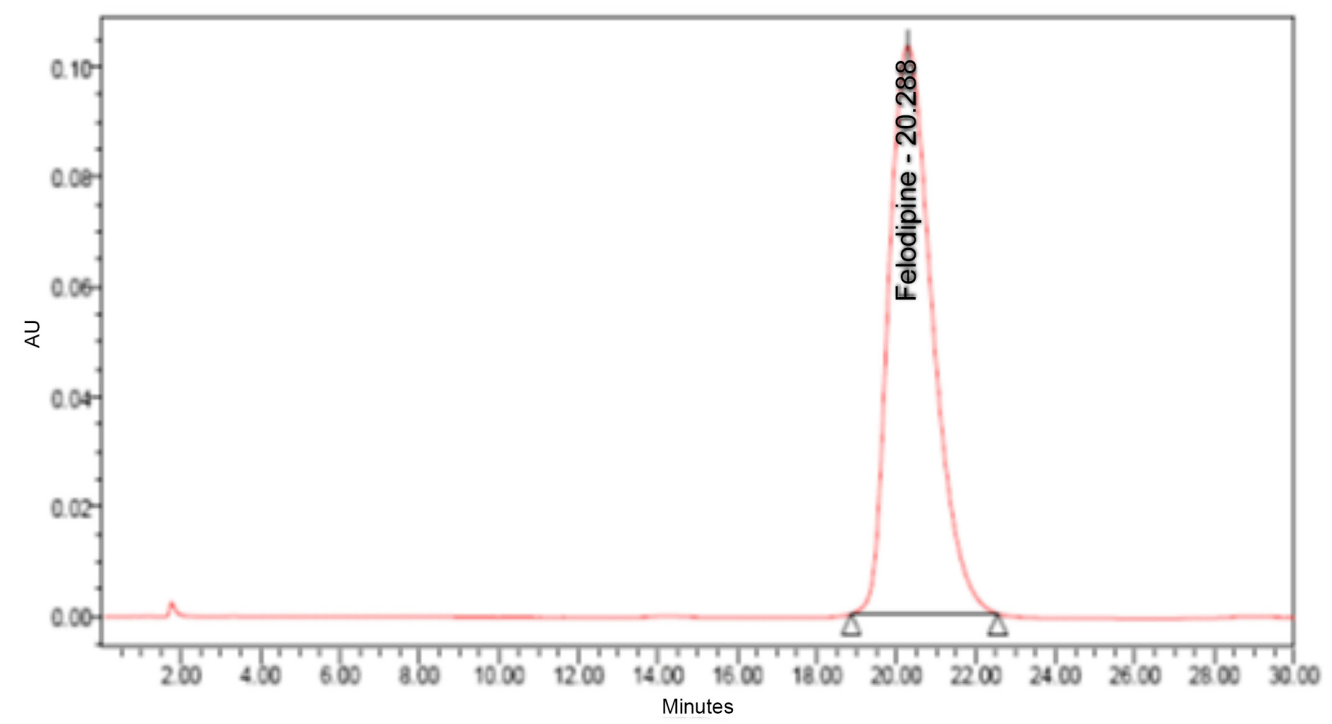

FIGURE 1 - HPLC Chromatogram of standard drug. 
appearance of resultant emulsion as clear (transparent with bluish tinge) and non-clear (turbid). Compositions were also evaluated for flowability by visual observation as the final aim was to fill the formulation into Hard Gelatin Capsules (HGCs).

\section{Construction of Pseudo ternary phase diagram}

Pseudo-ternary phase diagrams of oil, surfactant: co-surfactant and water were developed using water titration method. Mixtures of oil and surfactant to cosurfactant at certain weight ratios were diluted with water in a drop wise manner. For each phase diagrams at a specific ratio of surfactant to co-surfactant ( $\mathrm{S} /$ $\mathrm{CoS}), 2: 1,1.5: 1,1: 1$ and $0.5: 1(\mathrm{w} / \mathrm{w})$, transparent and homogenous mixture of oil and $\mathrm{S} / \mathrm{CoS}$ were formed by application of vortexing for $5 \mathrm{~min}$. Each mixture was further titrated with water and visually observed for phase clarity and flowability. The concentration of water at which turbidity-to-transparency and transparencyto-turbidity transitions occurred were derived from the weight measurements. These values were then used to determine the boundaries of the microemulsion domain corresponding to the chosen value of oils, as well as the $\mathrm{S} / \mathrm{CoS}$ mixing ratio. Phase diagrams were then constructed using Tri plot v1-4 software.

\section{Evaluation of FL loaded SMEDDS}

Optimized SMEDDS formulations were evaluated for robustness to dilution, globule size, in-vitro dissolution profile and dispersion time and precipitation.

- Robustness to dilution

Robustness of FL SMEDDS to dilution was studied by diluting it to 50,100 and 1000 times with various dissolution media viz. water, buffer $\mathrm{pH} 1.2$, buffer $\mathrm{pH} 4.5$ and buffer $\mathrm{pH}$ 6.8. The diluted microemulsions were stored for $12 \mathrm{~h}$ and observed for any signs of phase separation or drug precipitation.

- Emulsion droplet size analysis of FL SMEDDS

The size of FL SMEDDS formulations were determined by Delsa ${ }^{\mathrm{TM} N a n o} \mathrm{C}$ (Beckman Coulter, USA). SMEDDS formulation (100 $\mathrm{mg}$ ) was diluted with water to $500 \mathrm{ml}$ in a beaker and gently mixed using a glass rod. The resultant emulsion was further subjected to droplet size analysis using DelsaTM Nano.

- Determination of zeta potential

Zeta potential was measured by using DelsaTM Nano C (Beckman Coulter, USA). SMEDDS formulation $(100 \mathrm{mg})$ was diluted with water to $500 \mathrm{~mL}$ in a beaker and analyzed for zeta potential measuring instrument. All measurements were carried out at $25^{\circ} \mathrm{C}$

- Dispersion time and precipitation assessment

Dispersion time is defined as the time taken for lipid or surfactant based system to disperse in the dispersion medium (Khoo et al., 1998). In case of SMEDDS, it determines the time taken for pre-concentrate to form a well-dispersed, clear microemulsion. Dispersion time was determined using USP XXIV type 2 apparatus. Medium used for study was water and $0.1 \mathrm{~N}$ hydrochloric acid $(\mathrm{HCl})(500 \mathrm{~mL})$. The study was carried out by adding the formulation to the medium containing vessels and noting the time taken to form clear dispersion. The paddle shafts were rotated at $25 \mathrm{rpm}$ to provide gentle stirring. Precipitation was evaluated by visual inspection of resultant emulsion after $24 \mathrm{~h}$. The compositions were then categorized as stable (no precipitation at the end of $24 \mathrm{~h}$ ) and unstable (precipitation).

\section{Capsule filling}

The optimized FL SMEDDS were filled as unit doses in HGCs of size 4 having maximum volume of $0.21 \mathrm{~mL}$. Liquid filling was carried out at lab scale by accurately transferring measured dose (Formulation equivalent to 10 $\mathrm{mg}$ of FL) of formulation into body of capsules followed by sealing. The sealing was performed using organic solvent ethanol.

\section{Coating of FL SMEDDS capsules}

FL SMEDDS capsules were coated with a nonaqueous coat of $5 \% \mathrm{w} / \mathrm{v}$ ethyl cellulose dispersion (Dispersion medium - dichloromethane (DCM): isopropyl alcohol (IPA). The coating was carried out a lab-scale pan coater (Alfred Herbert Ltd., India) previously cleaned, dedusted. The coating liquid was filled into the spray gun with the help of attachment. All the essential parameters for coating are shown in Table II. As the capsules rolled, the film forming liquid was sprayed intermittently allowing

TABLE II - The adjusted process parameters during coating

\begin{tabular}{lc}
\hline Process variables & Adjusted specifications \\
\hline Pan design/Baffling & $12 \mathrm{~cm}$ diameter with 3 baffles \\
Rotational Speed of Pan & $30 \mathrm{rpm}$ \\
Spray Pressure (Operational) & $40-50$ p.s.i. \\
Bed to Gun Distance & $25-30 \mathrm{~cm}$ \\
Bed temperature & $30 \pm 5^{\circ} \mathrm{C}$ \\
Dry air temperature & $60 \pm 5^{\circ} \mathrm{C}$
\end{tabular}

Spray pattern type

Circular, occasionally elliptical 
the solvent to evaporate. The process was continued until the desired weight gain was achieved.

\section{Effect of different grades of polymer on time lag and release profile}

Three different grades of the hydrophobic polymer i.e. ethyl cellulose (N7, N10, N22) in the same concentration (10 mg wt. gain/capsule) were used for coating FL SMEDDS capsules. Coated capsules were evaluated for appearance, leakage, stability of cap and body of capsules, and drug content. Effects of these different grades of the coating polymer on the time lag and in-vitro drug release profile were studied.

\section{Effect of different types of plasticizers on time lag and release profile}

Different plasticizers viz. polyethyleglycol-400 (PEG-400), triethyl citrate (TEC), diethyl phthalate (DEP) and dibutyl phthalate (DBP) in the same concentration $(10 \% \mathrm{w} / \mathrm{w}$ of coating polymer) were used for coating FL SMEDDS capsules. Coated capsules were evaluated for appearance, leakage, stability of cap and body of capsules, and drug content. Effects of these different types of plasticizers on the time lag and in vitro drug release profile were studied.

\section{Effect of coating weight gain on time lag and release profile}

FL SMEDDS capsules were loaded with different weight gains of the coating polymer viz. $2.5 \%, 5 \%$ and $10 \%$. Coated capsules were evaluated for appearance, leakage, stability of cap and body of capsules and drug content. Effects of increasing coating weight gain (which is a function of coating thickness) on the time lag and invitro drug release profile were studied.

\section{Evaluation of FL SMEDDS chronotherapeutics capsules \\ - Rupture Test}

The time taken for the coat to rupture was determined visually. The SMEDDS capsules were subjected to dissolution in USPXXIV dissolution apparatus (Type II), using different media at $37^{\circ} \mathrm{C}$; paddle speed being $50 \mathrm{rpm}$. The time lag was defined as the time point at which the polymer coating rupture $(n=6)$.

- In vitro drug release study

In vitro drug release was carried out in distilled water, $\mathrm{pH}(1.2,4.5,6.8$, and 7.4$)$ buffers. In order to simulate GIT conditions in vivo, the drug release was also carried out in sequential buffer change i.e. $1.2 \mathrm{pH}$ buffer $(0-2 \mathrm{~h}), 4.5 \mathrm{pH}$ buffer (2-4 h) and followed next by $\mathrm{pH} 6.8$ buffer and then by $\mathrm{pH} 7.4$ buffer. The dissolution studies were carried out in $500 \mathrm{~mL}$ of buffer in USPXXIV dissolution apparatus (Type II) (Electrolab TDT-08L, Electrolab, India) paddle speed being $50 \mathrm{rpm}$ at $37 \pm 0.5^{\circ} \mathrm{C}$. The drug release was then determined spectrophotometrically at $362 \mathrm{~nm}(\mathrm{n}=6)$. The linearity concentration for in vitro drug release testing was $5-25 \mu \mathrm{g} / \mathrm{ml}$ in all the dissolution media. The linearity equation for FL in water, $\mathrm{pH} 1.2$ buffer, $\mathrm{pH} 4.5$ buffer, $\mathrm{pH} 6.8$ buffer and $\mathrm{pH} 7.4$ buffer were $\mathrm{y}=0.021 \mathrm{x}-0.017$, $\mathrm{y}=0.024 \mathrm{x}-0.008, \mathrm{y}=0.029 \mathrm{x}+0.003, \mathrm{y}=0.018 \mathrm{x}+0.001$ and $\mathrm{y}=0.0217 \mathrm{x}+0.0013$ respectively.

\section{RESULTS AND DISCUSSION}

The self-emulsifying formulations comprising oil, surfactants, co-surfactants, and drug should be a clear and monophasic liquid at ambient temperature when added in to aqueous phase and should have good solvent properties to allow visualization of the drug in solution (Basalious et al., 2010). Solubility studies were aimed at identifying suitable oil phase and surfactant to co-surfactant ratio for the development of FL SMEDDS formulation. Distinguishing the suitable oil, surfactant to co-surfactant ratio having maximal solubilizing potential for drug under investigation is very important to achieve optimum drug loading (Pouton, 2000; Embleton et al., 1997). Solubility of FL in different types of oils, surfactant and co-surfactant are shown in Figure 2. Solubility studies clearly indicated that amongst the various oils that were screened, lauroglycol FCC and Labrafill M1944 CS could solubilize relatively large amount of FL. Transcutol P (TP) was found to be a very efficient solubilizer for FL. As it is a very good solubilizer and absorption enhancer and

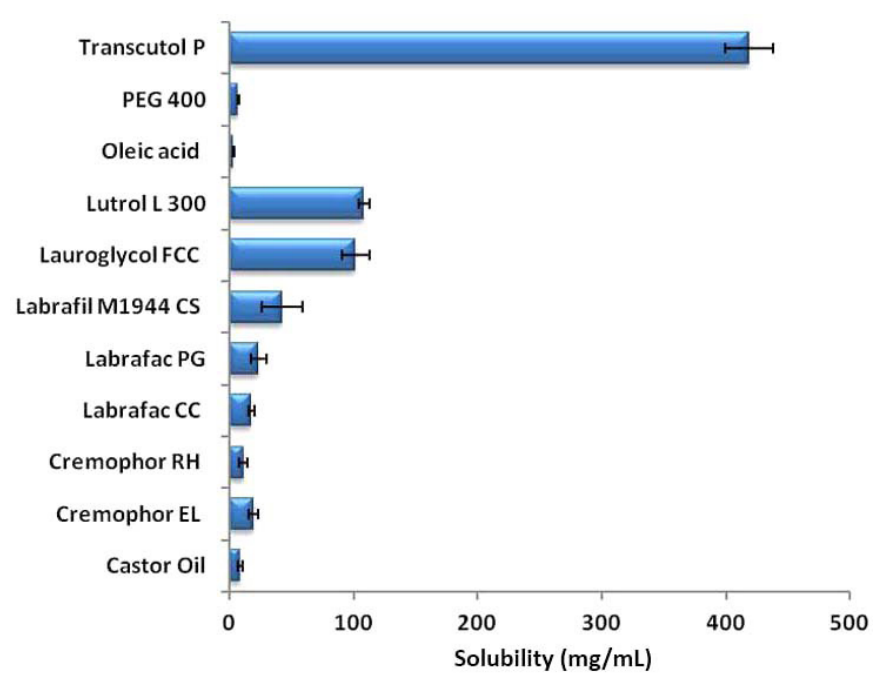

FIGURE 2 - Solubility of FL in various oils, Surfactants and Co-surfactants. 
TABLE III - Effect of surfactant to co-surfactant ratios on particle size, polysdispersity index, zeta potential, clarity and precipitation

\begin{tabular}{lccccc}
\hline S/CoS ratio & \multicolumn{5}{c}{ Evaluation parameters } \\
\cline { 2 - 5 } & $\begin{array}{c}\text { Particle size } \\
(\mathbf{n m})\end{array}$ & $\begin{array}{c}\text { Polydispersity } \\
\text { Index }\end{array}$ & $\begin{array}{c}\text { Zeta potential } \\
(\mathbf{m V})\end{array}$ & Clarity & Precipitation \\
\hline $0.5: 1.0$ & $231.33 \pm 10.2$ & $0.213 \pm 0.032$ & -15 & Clear & Unstable \\
$1.0: 1.0$ & $150.89 \pm 12.3$ & $0.292 \pm 0.091$ & -19 & Clear & Stable \\
$1.5: 1.0$ & $133.80 \pm 7.9$ & $0.119 \pm 0.024$ & -18 & Clear & Stable \\
$2.0: 1.0$ & $65.230 \pm 9.2$ & $0.211 \pm 0.031$ & -13 & Clear & Stable \\
\hline
\end{tabular}

$\mathrm{S} / \mathrm{CoS}=$ Surfactant to Co-surfactant ratio

thus was chosen as a co-surfactant in the development of SMEDDS formulations aiming to improve the drug loading capabilities.

The selection of surfactant or co-surfactant in the further study was governed by their emulsification efficiency and their ability to solubilise FL. Generally, surfactants are selected based on the continuous phase or disperse phase of the emulsion (hydrophilic surfactant for emulsion with aqueous phase as the dispersion phase and vice-versa). Since SMEDDS is meant to be diluted in aqueous phase to obtain microemulsion, inclusion of hydrophilic surfactant is an obvious choice. Among the surfactants screened during study, Cremophor EL (CEL) was found to give clear systems with lauroglycol FCC. The results demonstrated that TP was found to be a good co-surfactant in combination with CEL and thus it was selected for further studies. We have used CEL as surfactant and TP as co-surfactant in different ratios, which gives the FL SMEDDS with good emulsification and flowability characteristics as shown in Table III.

In the present investigation, lauroglycol FCC was tested for phase behavior studies with CEL and TP as $\mathrm{S} / \mathrm{CoS}$ mixture. As seen from the ternary plot (Figure 3 ), it was observed that lauroglycol FCC gave a wider microemulsion region at all $\mathrm{S} / \mathrm{CoS}$ ratios. Hence, lauroglycol FCC was found to be the preferred vehicle for the FL SMEDDS formulation. Figure 3 showed that the microemulsion existence was found to be increased by some extent with the increasing ratio of $\mathrm{S} / \mathrm{CoS}$ mixtures. These results are in agreement with the observations of initial trials of all batches with lauroglycol FCC. However, as mentioned above, increasing surfactant ratio resulted in loss of flowability. Thus, S/CoS ratio of 2:1 was selected for final FL SMEDDS formulation.

Microemulsions resulting from dilution of FL SMEDDS with various dissolution media were robust to all dilutions and did not show any separation even after $24 \mathrm{~h}$ of storage. The mean globule size of FL SMEDDS after dilution with various dissolution media is given in
Table IV. Optimized FL SMEDDS showed approximately similar mean globule size within range of $65-85 \mathrm{~nm}$ when diluted with various dissolution media of different $\mathrm{pH}$. The time required for formation of microemulsions after dilution with various dissolution media was less than 4 min. The resulting microemulsions were translucent in appearance and they did not show any signs of phase separation and drug precipitation even after $24 \mathrm{~h}$ of the storage. Thus, the formulated composition was found to be stable.

Ethyl cellulose was chosen as the coating polymer because of its weak mechanical strength and insolubility throughout the gastrointestinal tract. Though a not very flexible film is desired, the film formed must be strong enough to withstand the in-vivo GIT turbulences and remain intact for the period of "time lag". Therefore, various grades of ethyl cellulose differing in their viscosities were screened. Figure 4 (a) showed the drug release profile of the different batches coated with various grades of ethyl cellulose. The release profile indicates that as the viscosity of the polymer increases stronger and more durable films are formed. The thickness of film is not uniform all over the capsules; rupture is occurred were film thickness is thin compared to other part of film. The grade with the lowest viscosity (Ethyl Cellulose N7) showed good mechanical strength and rupture after the desired time lag.

Different plasticizers were used along with the film-forming polymer to produce good uniform film. Ethyl cellulose forms a tough however mechanically weak and brittle film and therefore plasticizers are added to increase film flexibility and to rupture after the desired time lag. Figure 4(b) showed the effect of different types of plasticizer on time lag. Hydrophilic plasticizers such as PEG 400 gave a very small time lag $(\sim 0.33 \mathrm{~h})$. This is due to the rapid dissolution of the plasticizer in the medium and formation of micro pores in the polymeric film coat through which the drug can diffuse out. As the lipophilicity of the plasticizer increased, an increase in time lag was 

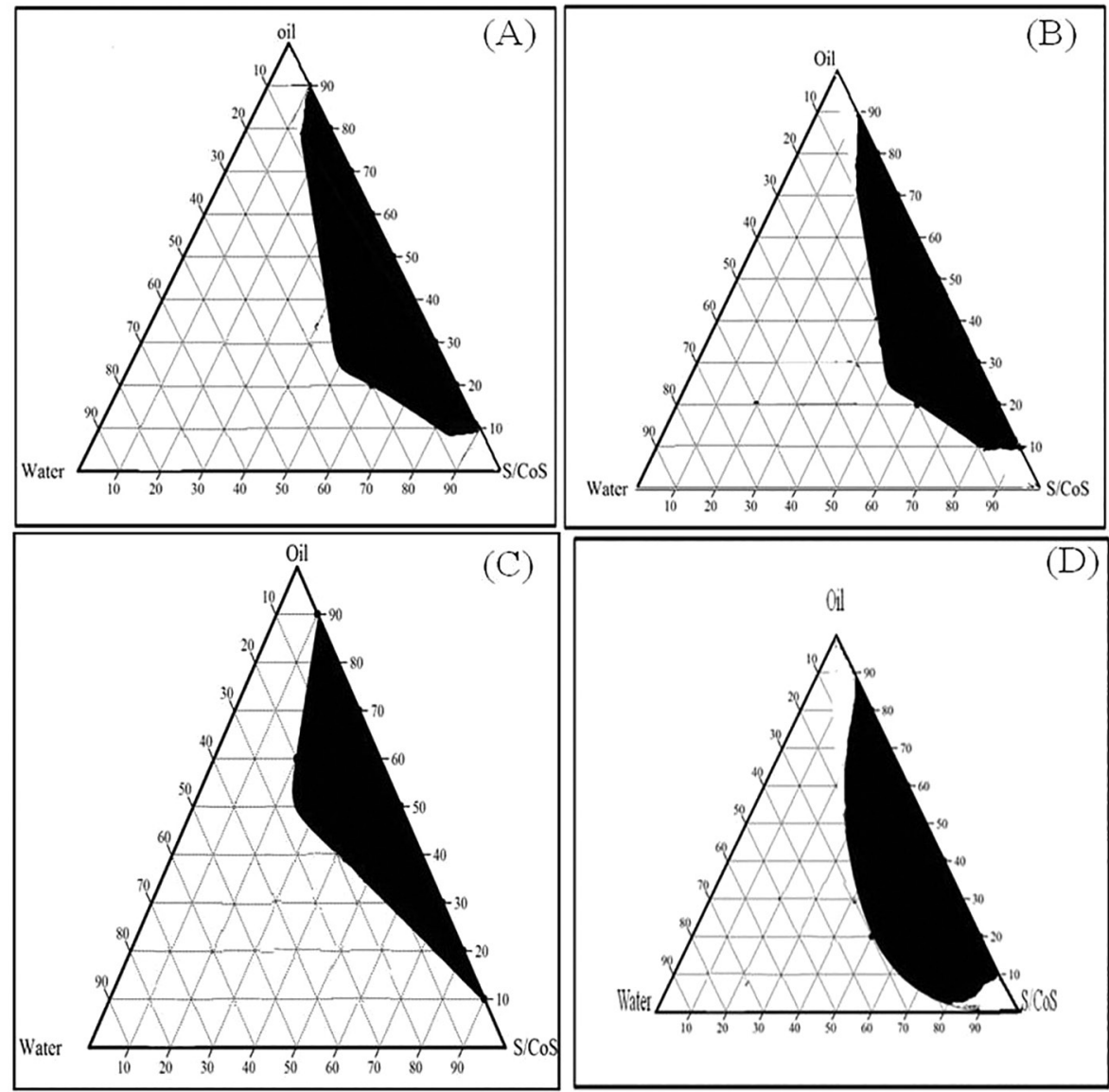

FIGURE 3 - Ternary phase diagrams of different selected systems dispersed in water at $25^{\circ} \mathrm{C}$. (Oil = lauroglycol FCC, Surfactant $=$ Chremophor EL, Co-surfactant $=$ Transcutol P) Ratio of surfactant to cosurfactant in (a) is 0.5:1, (b) is 1:1, (c) is 1.5:1 and (d) is 2:1. Dark area shows oil in water microemulsion region.

TABLE IV - Globule size and polydispersity index of FL SMEDDS at different $\mathrm{pH}$ conditions

\begin{tabular}{lcccc}
\hline Dissolution Medium & Water & Buffer pH 1.2 & Buffer pH 4.5 & Buffer pH 6.8 \\
\hline${\text { Globule size }(\mathrm{nm})^{\mathrm{a}}}^{\text {Polydispersity index }}{ }^{\mathrm{b}}$ & $65.34 \pm 2.3$ & $70.54 \pm 8.8$ & $68.45 \pm 4.7$ & $76.35 \pm 9.2$ \\
\hline
\end{tabular}

${ }^{a}$ Globule size expressed as mean $(n=3)$ where relative standard deviation was $<10 \%$. ${ }^{b}$ Polydispersity index expressed as mean $(\mathrm{n}=3)$.

observed. Films plasticized with dibutyl phthalate (DBP) gave desirable time lag $(\sim 6.0 \mathrm{~h})$ and subsequently desired in-vitro drug release profile. Hence, DBP was chosen as the plasticizer to get the desired drug release.

Increase in the coat thickness also cause resistance to the water penetration and coat rupture. Figure 5 (a) showed that with increase in the percent coating weight gain i.e. with increase in coat thickness there was a corresponding increase in the time lag of the formulation indicating that this parameter could be used to modulate and achieve a desired time lag. The desired released profile was obtained by $10 \%$ weight gain of the polymer coat. $\mathrm{pH}$ independent drug release behaviour of the polymer was also studied by carrying out the dissolution in sequential buffer change. As shown in Figure 5(b), drug release behaviour of the optimized formulation was found to be not affected by the $\mathrm{pH}$ of the medium. Thus, the developed formulation was showing $\mathrm{pH}$ independent release profile of FL owing to the use of ethyl cellulose as hydrophobic functional coating material.

\section{CONCLUSIONS}

The most significant issue to consider when 

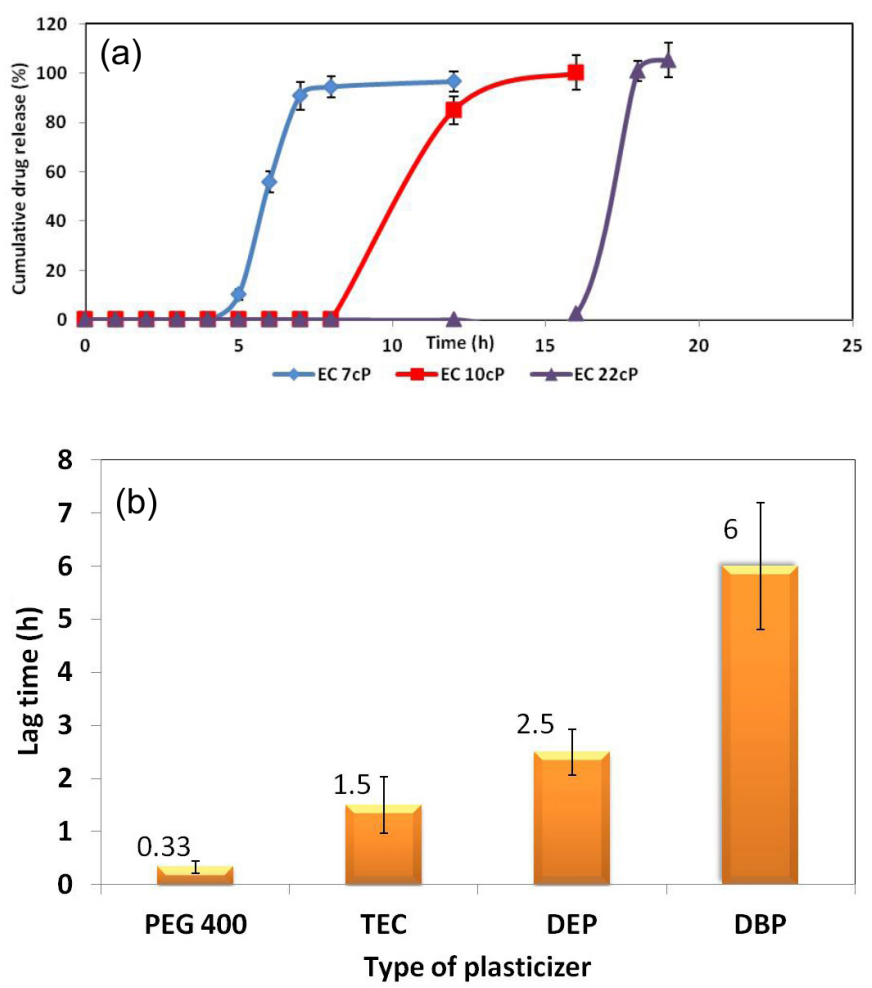

FIGURE 4 - (a) Effect of different grades of ethyl cellulose on time lag and in-vitro release profile (b) Effect of type of plasticizer on time lag (PEG 400: Polyethylene glycol 400, TEC: triethyl citrate, DEP: diethyl phthalate, DBP: dibutyl phthalate).
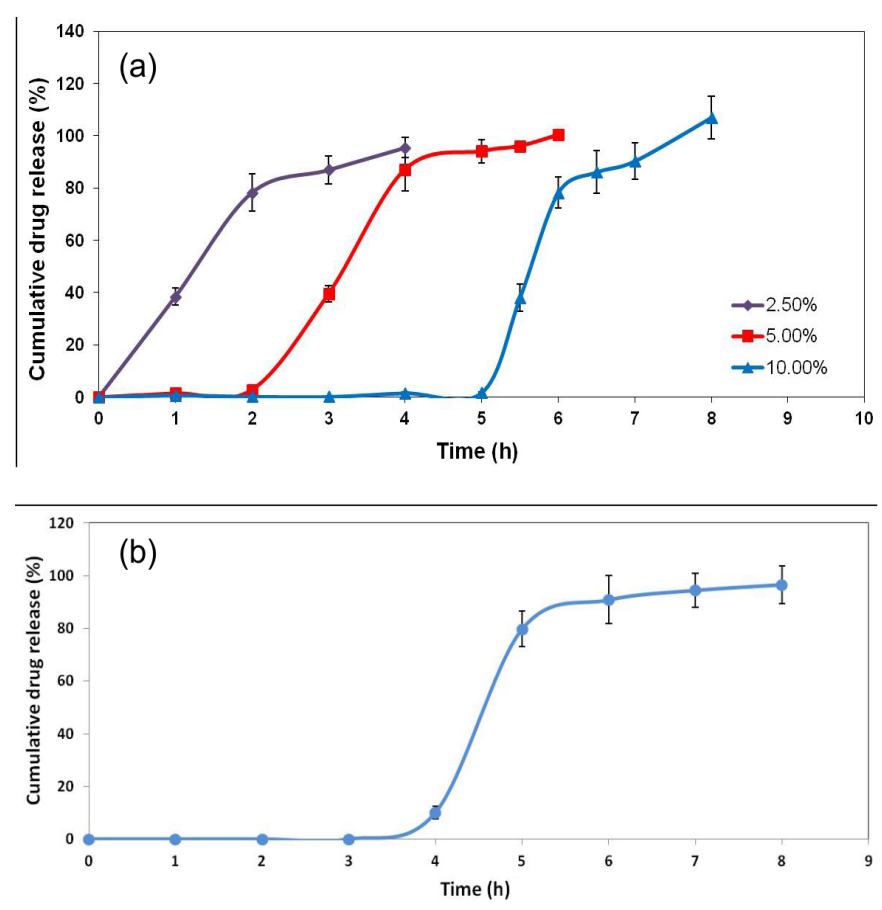

FIGURE 5 - (a) Effect of percent coating weight gain of ethyl cellulose on time lag and in-vitro release profile (b) Dissolution of optimized formulation in sequential buffer change. formulating chronotherapeutics delivery is to release drugs after a defined delay period (lag period-interval of no drug release) after being taken by the patient. Here, we have successfully developed SMEDDS of Felodipine to increase the bioavailability and filled in hard gelatine capsules coated with $\mathrm{pH}$ independent polymer. Thus, time dependent release of drug from the formulation to a specific time of the day was successfully achieved when there is maximal clinical manifestation of the disease.

\section{ACKNOWLEDGEMENTS}

Authors are thankful to University Grant Commission (UGC), Government of India, for financial assistance and AICTE for providing facilities to perform the experimental work.

\section{REFERENCES}

ABRAHAMSSON, B.; JOHANSSON, D.; TORSTENSSON, A.; WINGSTRAND, K. Evaluation of solubilizers in the drug release testing of hydrophilic matrix extended-release tablets of felodipine. Pharm. Res., v.11, n.8, p.1093-1097, 1994.

ANSARI, K.A.; TORNE, S.J.; VAVIA, P.R.; TROTTA, F.; CAVALLI, R. Paclitaxel loaded nanosponges: in-vitro characterization and cytotoxicity study on MCF-7 cell line culture. Curr. Drug Deliv., v.8, n.2, p.194-202, 2011.

ANSARI, K.A.; VAVIA, P.R.; TROTTA, F.; CAVALLI, R. Cyclodextrin-based nanosponges for delivery of resveratrol: in vitro characterisation, stability, cytotoxicity and permeation study. AAPS PharmSciTech., v.12, n.1, p.279286, 2011.

BASALIOUS, E.B.; SHAWKY, N.; BADR-ELDIN, S.M. SNEDDS containing bioenhancers for improvement of dissolution and oral absorption of lacidipine. I: development and optimization. Int. J. Pharm., v.391, n.1-2, p.203-211, 2010.

BEHRENS, S.; EHLERS, C.; BRUGGEMANN, T. Modification of the circadian pattern of ventricular tachyarrhythmias by beta-blocker therapy. Clin. Cardiol., v.20, n.3, p.253-257, 1997.

COHEN, M.C.; ROTHLA, K.M.; LAVERY, C.E.; MULLER, J.E.; MITTLEMAN, M.A. Meta analysis of the morning excess of acute myocardial infarction and sudden cardiac death. Am. J. Cardiol., v.79, n.11, p.1512-1516, 1997. 
DATE, A.; NAGARSENKER, M.S. Design and evaluation of self-nanoemulsifying drug delivery systems (SNEDDS) for cefpodoxime proxetil. Int. J. Pharm., v.329, n.1-2, p.166$172,2007$.

EMBLETON, J.K.; POUTON, C.W. Structure and activity of gastro- intestinal lipases. Adv. Drug Delivery Rev., v.25, n.1, p.15-32, 1997.

EVANGELOS, K.; EMMANOUEL, G.; DIMITRIOS, B. Felodipine nanodispersions as active core for predictable pulsatile chronotherapeutics using PVP/HPMC blends as coating layer. Int. J. Pharm., v.313, n.1-2, p.189-197, 2006.

FRANCIS, L.; ALPER, O.; SANDRINE, D.; PASQUALE, F.I.; JEAN, C. Circadian timing in cancer treatments. Annu. Rev. Pharmacol. Toxicol., v.50, p.377-421, 2010.

HERMIDA, R.C.; AYALA, D.E.; PORTALUPPI, F. Circadian variation of blood pressure: the basis for the chronotherapy of hypertension. Adv. Drug Delivery Rev., v.59, n.9-10, p.904-922, 2007.

HONG, J.Y.; KIM, J.K.; SONG, Y.K.; PARK, J.S.; KIM, C.K. A new self-emulsifying formulation of itraconazole with improved dissolution and oral absorption. J. Control. Release, v.110, n.2, p.332-338, 2006.

KARAVAS, E.; GEORGARAKIS, E.; BIKIARIS, D. Application of PVP/HPMC miscible blends with enhanced mucoadhesive properties for adjusting drug release in predictable pulsatile chronotherapeutics. Eur. J. Pharm. Biopharm., v.64, n.1, p.115-126, 2006.

KHOO, S.M.; HUMBERSTONE, A.J.; PORTER, C.J.; EDWARDS, G.A.; CHARMAN, W.N. Formulation design and bioavailability assessment of lipidic self-emulsifying formulations of Halofantrine. Int. J. Pharm., v.167, n.1-2, p.155-164, 1998.

LEMMER, B. Circadian rhythms and drug delivery. $J$. Controlled Release, v.16, n.1-2, p.63-74, 1991.

LEMMER, B. The importance of biological rhythms in drug treatment of hypertension and sex-dependent modifications. ChronoPhysiology and Therapy, v.2, p.9-18, 2012.

MANDAL, A.S.; BISWAS, N.; KARIM, K.M.; GUHA, A.; CHATTERJEE, S.; BEHERA, M.; KUOTSU, K. Drug delivery system based on chronobiology-A review. $J$. Controlled Release, v.147, n.3, p.314-325, 2010.
MICHAEL, H.S.; NICHOLAS, A.P. Chronobiology, drug delivery and chronotherapeutics. Adv. Drug Deliv. Rev., v.59, n.9-10, p.828-851, 2007.

NAYAK, U.Y.; SHAVI, G.V.; NAYAK, Y; AVERINEN, R.K.; MUTALIK, S.; REDDY S.M.; GUPTA, P.D.; UDUPA, N. Chronotherapeutic drug delivery for early morning surge in blood pressure: A programmable delivery system. $J$. Controlled Release, v.136, n.2, p.125-131, 2009.

NEKKANTI, V.; VENKATESWARLU, V.; AKHTER ANSARI, K.; PILLAI, R. Development and pharmacological evaluation of a PEG based nanoparticulate camptothecin analog for oral administration. Curr. Drug Deliv., v.8, n.6, p.661-666, 2011.

PATIL, P.R.; BIRADAR, S.V.; PARADKAR A.R. Extended release felodipine self-nanoemulsifying system. AAPS PharmSciTech., v.10, n.2, p.515-523, 2009.

POUTON, C.W. Formulation of poorly water-soluble drugs for oral administration: physicochemical and physiological issues and the lipid formulation classification system. Eur. J. Pharm. Sci., v.29, n.3-4, p.278-287, 2006.

POUTON, C.W. Lipid formulation for oral administration of drugs: non-emulsifying, self-emulsifying and selfmicroemulsifying drug delivery systems. Eur. J. Pharm. Sci., v.11, n.2, p.S93-S98, 2000.

RIDHURKAR, D.N.; ANSARI, K.A.; KUMAR, D.; KAUL, N.S.; KRISHNAMURTHY, T.; DHAWAN, S.; PILLAI, R. Inclusion complex of aprepitant with cyclodextrin: evaluation of physico-chemical and pharmacokinetic properties. Drug Dev. Ind. Pharm., v.39, n.11, p.1783-1792, 2012.

TORNE, S.J.; ANSARI, K.A.; VAVIA, P.R.; TROTTA, F.; CAVALLI, R. Enhanced oral paclitaxel bioavailability after administration of paclitaxel-loaded nanosponges. Drug Deliv., v.17, n.6, p.419-425, 2010.

TEBEREKIDIS, V.I.; SIGALAS, M.P. Theoretical study of hydrogen bond interactions of felodipine with polyvinyl pyrrolidone and polyethyleglycol. J. Mol. Struc.THEOCHEM., v.803, n.1-3, p.29-38, 2007.

TROTTA, F.; CAVALLI, R.; MARTINA, K.; BIASIZZO, M.; VITILLO, J.; BORDIGA, S.; VAVIA, P.; KHALID, A. Cyclodextrin nanosponges as effective gas carriers. J. Incl. Phenom. Macrocycl. Chem., v.71, n.1, p.189-194, 2011. 
UNITED STATES PHARMACOPOEIA. 29.ed. Rockville: United States Pharmacopeial Convention, 2006. 884 p.

WANG, Z.; SUN, J.; WANG, Y.; LIU, X.; LIU, Y.; FU, Q.; MENG, P.; HE, Z. Solid self-emulsifying nitrendipine pellets: preparation and in vitro/in vivo evaluation. Int. J. Pharm., v.383, n.1-2, p.1-6, 2010.

WASAN, E.K.; BARTLETT, K.; GERSHKOVICH, P.; SIVAK, O.; BANNO, B.; WONG, Z.; GAGNON, J.; GATES, B.; LEON, C.G.; WASAN, K.M. Development and characterization of oral lipid-based amphotericin B formulations with enhanced drug solubility, stability and antifungal activity in rats infected with Aspergillus fumigatus or Candida albicans. Int. J. Pharm., v.372, n.1-2, p.76-84, 2009.
YASIR, M.; ASIF, M.; KUMAR, A.; AGGARVAL, A. Biopharmaceutical Classification System:An Account. Int. J. Pharm. Tech. Res., v.2, n.3, p.1681-1690, 2010.

YOUAN, B.C. Chronopharmaceutics: gimmick or clinically relevant approach to drug delivery? J. Controlled Release, v.98, n.3, p.337-353, 2004.

Received for publication on $13^{\text {th }}$ December 2012 Accepted for publication on $02^{\text {nd }}$ November 2013 